УДК 311.21:[314.14:614.8](477+061.1€С)

JEL Classification: C82, J11, N30

Doi: 10.31767/su.2-3(89-90)2020.02-03.11

N. O. Ryngach,

DSc in Public Administration, Senior Research Fellow,

Leading Research Fellow,

Ptoukha Institute for Demography and Social Studies

of the National Academy of Sciences of Ukraine

E-mail: n_ryngach@ukr.net; n_ryngach@idss.org.ua

ResearcherID: X-3983-2018,

ORCID: https://orcid.org/0000-0002-5916-3221

\title{
Mortality Due to External Causes in Ukraine: Lives That Could Be Saved
}

The article's objective is to assess the losses of human lives in Ukraine, resulting from the mortality due to external causes (by absolute number, rate and structure), reveal the patterns by gender and age, with distribution by main cause. A comparative analysis of the mortality due to external causes in Ukraine and other countries is made by data on the distribution of deaths by gender, age and cause of death, taken from the State Statistics Service of Ukraine, international and national databases. It is shown that the major share of deaths were due to four main causes accounted for more than $68 \%$ of all the cases: intentional self-harm (suicides); harm of undetermined intent; accidental poisonings caused by noxious substances; and transport accidents.

An essential gender disproportion due to external causes is revealed: the mortality rate of males is 4.7 times higher than females. In Ukraine males account for $80.2 \%$ of the total deaths due to external causes (against two thirds, or $64.2 \%$, in EU). The excess of males is the most significant in the causes such as drowning, suicides and accidental poisonings (with more than eight times to six times excess of the respective figure over females). In view of this, the share of deaths due to external causes in the overall structure of mortality was higher for Ukrainian males (8.4\%) than for females $(2.0 \%)$.

The rate of sudden mortality (in the age younger than 65) due to external causes of death in Ukraine is 2.5 time higher than in Sweden chosen as a reference country, and thrice higher than in EU until 2004. The majority of deaths due to external causes in Ukraine are concentrated in this age group: nearly $80 \%$ in 2019 (against $49 \%$ in EU countries).

A pressing social problem for modern Ukraine is the excessive mortality due to accidental poisoning and alcohol effects: from the age of 30 years and on, such cases exceed the poisonings caused by noxious substances (the gap being 1.75 times for the total population and more than trice (3.25 times) for the middle age of 45-49 years.

Special attention is given to the problem of the increasing rate of deaths classified as "harm with undetermined intent" (which rate in Ukraine is seven times higher than in EU). It raises the need for analysis of the veracity of determined causes of death and quality enhancement of the official statistics for this class of causes in Ukraine, to have better understanding of the real situation and tendencies of change in the epidemiological situation with respect to external causes of mortality.

Key words: mortality, external causes, intentional harm, unintentional harm, structure by main cause of death, suicide, accidental poisonings caused by noxious substances, transport accidents, homicides, harm with undetermined intent, demographic losses, sudden mortality.

Introduction. A pressing social problem in present-day Ukraine is a high rate of mortality due to external causes (ECs), entailing heavy losses of lives in young and able-bodied age. The majority of developed countries witnessed a positive change within the second epidemiological revolution, manifested in the considerably extended control over non-infection causes of death, e. g. deceases of the blood circulation system, neoplasms, chronic deceases of lights, sugar diabetes etc., as well as ECs. This resulted in the shift of deaths from ECs to older age

(c) N. O. Ryngach, 2020 groups, with the increasing average age of death from ECs and the considerably grown life expectancy in the consequence [1]. The Ukraine's lagging behind developed countries by the latter indicator is caused, above all, by the failure to set up the similarly effective control over the ECs of death. It should be stressed that any kind of unnatural death is a sudden one, no matter when it happens: in the age of one year or one hundred years. With few exceptions, the mortality due to ECs is the one that can be prevented. Unlike chronic non-infection deceases, when the effect from combat strategies needs to be waited long enough, the efficient measures to combat the mortality due 
unnatural causes can result in the reduced mortality rate in the forthcoming years. Thus, the norm on the obligatory safety belts introduced in the countries has strong impact on the death rate due to road traffic accidents.

The class "External causes of morbidity and mortality" includes the nomenclature of already distinct causes that can be divided by intent (violent and non-violent), mechanism and localization of injury, factor of injury etc. Extremely important is analysis of various components of this structure and change in their percentage over time, identification and comprehension of factors with impact on the death rate due to ECs, which determine preventive measures. Thus, the mortality due to ECs is essentially different by rate and structure with males and females, by age group etc. All the above has extreme importance for organization of counteractive measures against "epidemic" of injuries and accidents, which determines the topicality of this study.

Literature review. A. Vishnevskyi, a wellknown Russian demographer, notes that prevention of unnatural causes of death should be given special attention in the current phase of death reduction, with the combat of non-infection causes of death (new phases of epidemiological transition, the second epidemiological revolution) being at the top of the agenda. He stresses that the losses due to the mortality from ECs in Russia are underestimated, with implications for the priorities of the national health protection system [1;2]. At the global scales, the estimated number of deaths due to violence and injuries are admittedly higher than the one reported by the official statistics [3]. According to the World Health Organization (WHO), nearly half million (493.500) lives in the European region of WHO were lost in 2016 as a result of injuries and violence [4].

The recent report "Violence and injuries in Europe" (2020) informs that in 2000-2016 the death rate due to all the categories of injuries in the European region of WHO fell by $30 \%$, but this progress was uneven across countries: the death rate varied from 65 percent reduction to 6 percent growth. The proper control over the observation of law helps reduce road traffic traumatism; limitations on the access to lethal means and tools (weapons in the first place) helps prevent suicide; limitations on the access to water for small children can reduce the risk of drowning; support to and education for parents/guardians helps prevent violence against children; keeping physical abilities and the ability to keep the balance by older people prevents injuries of the fall. It is stressed that violence and injuries cause half of the total deaths with the people aged 15-29, one third of the deaths with children aged 5-14, and one quarter of the deaths with adults aged 30-49. In overall, $42 \%$ of these death cases are accounted for by people younger than 50. In view of the above, special attention drawn to the prevention of violence and injuries in the Sustainable Development Goals is reasonable and justified. There is a need in rapid development and expansion of measures that have to be based on scientifically valid data, for the benefit of future generations [4].

Analyses of the situation with losses due to the mortality from unnatural causes, monitoring and publishing its characteristics are a priority action of national governments. On the website of the U.S. National Center for Health Statistics, the data on deaths from ECs are grouped and displayed on six dashboards: by mechanism; by intent; by sex; by age group; by race (with separate presentation of the group of Hispanic origin); and by mechanism and intent interaction [5]. In 2016, $68.6 \%$ of the total deaths in the U.S. were caused by unintentional injuries and only $2.5 \%$ by injuries with undetermined intent. Table 1 (constructed by data from the U.S. National Center for Health Statistics, [5]) illustrates the variations depending on ethnical belonging (for black, white race and persons of Hispanic origin) [6]. Here and below, unless specified otherwise, death rates are presented as an age-adjusted index (Eurostandard), per 100,000 population.

Age-adjusted death rates by selected intent(s) of injury, by race, the U.S., 2016

\begin{tabular}{|c|c|c|c|c|c|c|c|c|}
\hline \multirow[b]{2}{*}{$\begin{array}{l}\text { Cause of death } \\
\text { by intent }\end{array}$} & \multicolumn{2}{|c|}{ All races } & \multicolumn{2}{|c|}{ Non-Hispanic Black } & \multicolumn{2}{|c|}{ Non-Hispanic white } & \multicolumn{2}{|c|}{ Hispanic origin } \\
\hline & $\begin{array}{l}\text { per } 100,000 \\
\text { population }\end{array}$ & $\%$ & $\begin{array}{c}\text { per } 100,000 \\
\text { population }\end{array}$ & $\%$ & \begin{tabular}{|c|} 
per 100,000 \\
population
\end{tabular} & $\%$ & \begin{tabular}{|c|} 
per 100,000 \\
population
\end{tabular} & $\%$ \\
\hline $\begin{array}{l}\text { All intentions, } \\
\text { including: }\end{array}$ & 69.0 & 100 & 75.7 & 100 & 76.0 & 100 & 44.2 & 100 \\
\hline - unintentional & 47.3 & 68.7 & 44.2 & 58.6 & 53.8 & 70.9 & 31.3 & 71.2 \\
\hline $\begin{array}{l}\text { - intentional, } \\
\text { including: }\end{array}$ & 19.7 & 28.8 & 29.0 & 38.5 & 19.8 & 26.3 & 11.9 & 27.2 \\
\hline suicides & 13.5 & 19.7 & 6.2 & 8.2 & 17.0 & 22.5 & 6.7 & 15.3 \\
\hline homicides & 6.2 & 9.1 & 22.8 & 30.3 & 2.8 & 3.8 & 5.2 & 11.9 \\
\hline $\begin{array}{l}\text { - intent } \\
\text { undetermined }\end{array}$ & 1.7 & 2.5 & 2.2 & 2.9 & 2.1 & 2.8 & 0.6 & 1.6 \\
\hline
\end{tabular}


K. Shcherbakova makes a review of Eurostat data and points out that the share of deaths from ECs has been gradually reducing. It fell from $5.2 \%$ to $4.5 \%$ in 1994-2010 in EU-15, and from 5.3\% in 2000-2001 to 4.6\% in 2012-2013 in EU-28, with the mortality before reaching the age of 65 declining more rapidly [7]. In the European region of WHO, the mortality due to ECs is uneven across countries, which rate is 1.5 times higher in the group of middle income countries (in which Ukraine is classified) compared with the group of high income countries. When all the specificities of the age structure are accounted, the figures of mortality in countries with middle and high income will be converging [4].

Analysis of the structure of mortality due to ECs by cause, understanding of their recording specifics, cultural features and traditions of countries, attitudes of societies to particular events and political or administrative directives etc. is an issue of importance. Russian scientist V. Yumazin showed that a reduction in the mortality from homicides and suicides in the country took place in parallel with the growing mortality from injuries with undetermined intent (for males the cumulative share of the three causes increased from $28 \%$ to $47 \%$ since 1960 s). This allowed him to make a suggestion that a part of homicides and suicides is recorded as deaths due to injuries with undetermined intent, which results in the artificial underestimation of the number of violent deaths in Russia [1, p. 328-378; 8]. Approaches to re-qualification of death causes in the cases included in this category were proposed $[9 ; 10]$.

Methods and materials. The information base for the study is official data from the State Statistics Service of Ukraine on the distribution of deaths by gender, age group and cause of death; mortality by gender and cause of death (European standard) for the year of 2019. A comparative analysis is made using the respective data from international (Eurostat, HFAMDB, Statista) and national databases (National Center for Health Statistics (the U.S.); Statistics Poland та Statistics Sweden).

Computations were made using the officially recorded data on mortality, included by the International Statistical Classification of Deceases and Related Health Problems (ICD, revision 10, ICD-10) in Class XX "External Causes of Morbidity and Mortality" (code V01-Y89) for all the indicators under study. It should be noted that Ukraine introduced the coding of mortality by ICD-10 in 2005 .

Results. More than 30,000 (as exactly as 30,009) death cases caused by external factors (Class XX) were recorded in 2019. The recent years witnessed a considerable change both in the mortality due to ECs and in its structure, which evidence in given in Table 2 constructed by data [10, p. 126]. (Here and below the data on Ukraine are presented without inclusion of the temporarily occupied territory of the Autonomous Republic of Crimea (ARC), the city of Sevastopol and the part of the temporarily occupied territories of Donetsk and Luhansk regions).

Compared with 2005, the absolute number of death cases due ECs fell by more than twice (from 2013 the reduction made one quarter!), and their share in the structure of mortality due to all the causes reduced as well. On the one hand, this can be attributed to noninclusion of data for ARC and especially for the Donbas region encompassing densely populated areas where a high mortality rate used to be recorded, with the mortality due to ECs higher than the national average. On the other hand, a slow reduction in the mortality resulting from ECs may be related with the declining number of the country's population.

Table 2

The mortality by main cause of death, Ukraine, 2005-2019

\begin{tabular}{|c|c|c|c|c|c|c|c|}
\hline \multirow{3}{*}{ Year } & \multirow{3}{*}{ Total } & \multicolumn{6}{|c|}{ By cause } \\
\hline & & \multicolumn{2}{|c|}{$\begin{array}{l}\text { deceases of the blood } \\
\text { circulation system }\end{array}$} & \multicolumn{2}{|c|}{ neoplasms } & \multicolumn{2}{|c|}{ external causes } \\
\hline & & $\begin{array}{l}\text { number of } \\
\text { persons, } \\
\text { thousand }\end{array}$ & share, \% & $\begin{array}{l}\text { number of } \\
\text { persons, } \\
\text { thousand }\end{array}$ & share, \% & $\begin{array}{l}\text { number of } \\
\text { persons, } \\
\text { thousand }\end{array}$ & share, \% \\
\hline 2005 & 782.0 & 488.8 & 62.5 & 91.8 & 11.7 & 70.0 & 9.0 \\
\hline 2006 & 758.1 & 480.8 & 63.4 & 90.4 & 11.9 & 64.6 & 8.5 \\
\hline 2007 & 762.9 & 480.6 & 63.0 & 90.0 & 11.8 & 66.0 & 8.7 \\
\hline 2008 & 754.5 & 480.1 & 63.6 & 89.0 & 11.8 & 61.4 & 8.1 \\
\hline 2009 & 706.7 & 460.6 & 65.2 & 88.6 & 12.5 & 48.9 & 6.9 \\
\hline 2010 & 698.2 & 465.1 & 66.6 & 88.8 & 12.7 & 44.0 & 6.3 \\
\hline 2011 & 664.6 & 440.3 & 66.3 & 89.0 & 13.4 & 42.4 & 6.4 \\
\hline 2012 & 663.1 & 436.4 & 65.8 & 92.9 & 14.0 & 41.7 & 6.3 \\
\hline 2013 & 662.4 & 440.4 & 66.5 & 92.3 & 13.9 & 40.3 & 6.1 \\
\hline 2014 & 632.3 & 425.6 & 67.3 & 83.9 & 13.3 & 40.1 & 6.3 \\
\hline 2015 & 594.8 & 404.6 & 68.0 & 79.5 & 13.4 & 34.6 & 5.8 \\
\hline 2016 & 583.6 & 392.3 & 67.2 & 79.0 & 13.5 & 31.7 & 5.4 \\
\hline 2017 & 574.1 & 384.8 & 67.0 & 78.3 & 13.6 & 31.2 & 5.4 \\
\hline 2018 & 587.7 & 392.1 & 66.7 & 78.6 & 13.4 & 30.9 & 5.3 \\
\hline 2019 & 581.1 & 389.3 & 67.0 & 78.2 & 13.5 & 30.0 & 5.2 \\
\hline $\begin{array}{l}\text { Reduction } \\
2013 / 2019, \%\end{array}$ & 12.3 & 11.6 & - & 15.3 & - & 25.6 & - \\
\hline
\end{tabular}


It should be noted that in Ukraine, being engaged in a military conflict, the number of losses classified as "injuries due to military actions" recorded in 2019 was lower than in previous years (only 111 cases).

The distribution of the deaths due to ECs in Ukraine is essentially different from the distribution of the total deaths. In 2019, the age group younger than 65 was responsible for $79.6 \%$ of the deaths due to ECs, and only for $29.05 \%$ of the total deaths. Compare: in EU countries the share of total deaths is only $18 \%$ in the age group younger than 65 , and the share of deaths due to ECs is $49 \%$.

Gender and age specifics. The significance of ECs of death in Ukraine greatly varies across gender and age groups. While in the group of babies who usually can stay without adults' care (mother or persons responsible for care) quite a short time, the share of such deaths is small (less than 5\%), in the age group from one to five years ECs are responsible for more than one of the four deaths.

As a child grows up, the risk of death caused by external factors increases due to the expanding contacts with the outer world and gaining of independence, and due to the gradual loosening of adults' care. Before reaching the age of 15 years, the share of such deaths increases to nearly half (43.8\%) of the total deaths, and for the age group 15-19 it exceeds the half (64.2\%). For the youth aged 15-24, unnatural factors of death cause nearly two thirds of the total deaths.

The significance of mortality due to ECs increases for males upon reaching the age of one year. In the age group of 5-9, the share of ECs in the structure of mortality is twice higher for boys than for girls; as the age grows, this proportion, although fluctuating, keeps within the range of 1.5-2 times. Fig. 1 (computations made using the data from the State Statistics Service of Ukraine) illustrates change in the share of deaths due to ECs for males and females by age category.

This share was the largest (69.1\%) in 2019 for young males aged 20-24 (for teenagers of 15-19 years it is slightly less, i. e. 67.4\%!). For females this share was the largest in the same age groups, with the lower peak (56.1\%) recorded for the age group of 15-19. The weight of ECs decreases with growing up of children (more rapidly for females). This can be attributed to several factors: gaining of life experience; weaker inclinations to get into situations with risks to one's life; occurrences of other deceases that may cause death etc. Also, there is an opinion that a part of deaths due to ECs among the older age groups are not reported because of inaccurate determination of death causes or unwillingness to investigate death circumstances; as a result, a death may be reported as the one caused by cardiovascular decease or old age [11].

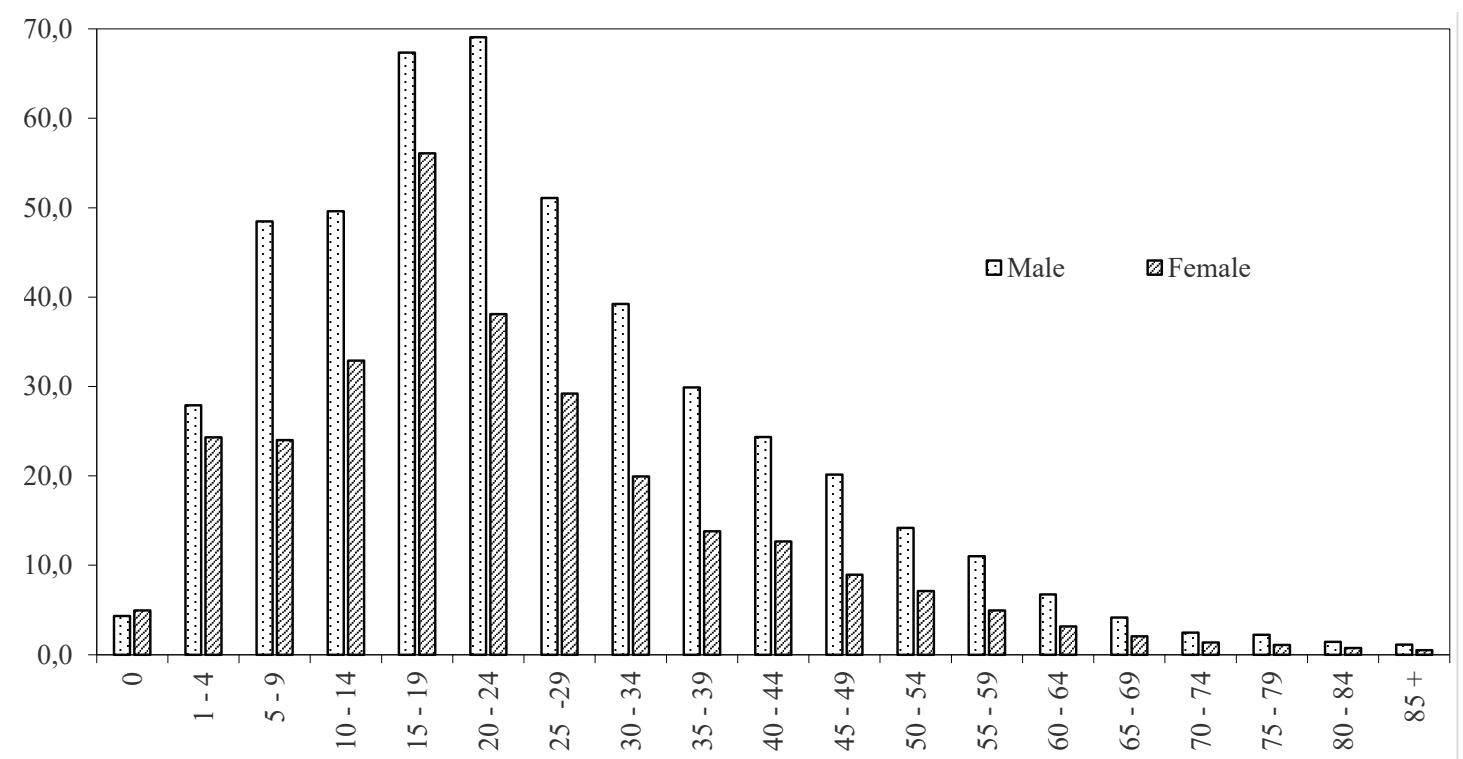

Figure 1. The share of deaths from external causes in the structure of mortality, by gender and age, Ukraine, 2019, \%

According to the State Statistics Service of Ukraine, in 2019 the mortality due to ECs was, for both genders, 78.1 per 100,000 of population. The highest mortality due to ECs was recorded for the group of the population in the working age, but the figure for the older population (males of 60 years and older and females of 55 years and older) proved to be a slightly lower (Figure 2, constructed by data from the State Statistics Service of Ukraine, form TC-2 "Death rates by sex, age group and death cause"). 


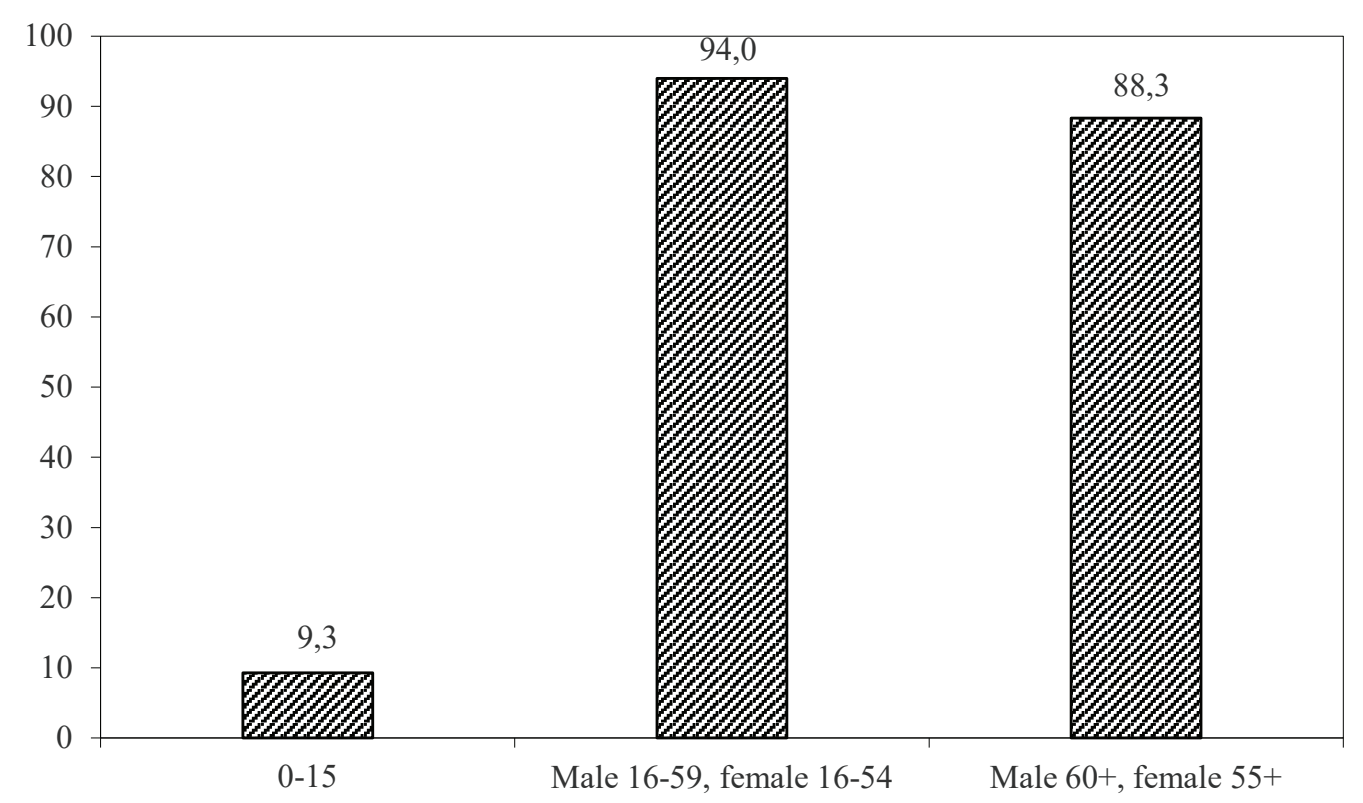

Figure 2. The mortality from external causes by aggregated age groups, Ukraine, 2019, per 100,000 of the respective group

Distribution of deaths by external cause. One fifth of the reported deaths due to ECs in Ukraine were the deaths of the population resulting from intentional self-harm (suicides). The second rank, with a slightly lower figure, is with the harms of undetermined intent; the third rank is shared by transport accidents and accidental poisonings caused by intoxicating substances.

It should be noted that a significant share of deaths caused by harms (injuries, poisonings etc.) that could not be classified (homicide, suicide or accident) gives evidence of defects in determining death causes in a given country, with adverse effects for the quality of the official statistics. S.Vasin labels it a phenomenon of turning socially significant causes into the latent form [12].

Another cause worth attention is accidental fall. The mortality in EU reduced in all the main ECs groups in 2002-2013 except for this one (its increase was $8 \%$ in 2009-2013) [7]. In 2016, the share of falls was even slightly higher than the share of suicides (23.8\% and $22.8 \%$ respectively). In Ukraine, 1905 deaths caused by falls (against 1908 in 2017) were recorded in 2019, with only 463 cases in the age group older than 70 . This gap between European countries and Ukraine, given the rapidly ageing population in Ukraine, makes one suggest that such deaths are underreported.

Another significant cause became accidental poisoning and alcohol effects, which caused 2774 deaths in Ukraine (of which 2581 deaths occurred in the age group from 15 to 65 years). "Accidental alcohol poisoning" sounds bizarre for a sober mind, as it is unlikely that somebody takes a lethal dose of an intoxicating drink accidentally. So, "accidentally" means that a person drinking alcohol had no intent of poisoning to death. Of 2774 abovementioned deaths, no case was recorded for the age group younger than 18 (i. e. in the age when a human, being immature, is not very well aware of a probable lethal effect of his/ her degustation of an intoxicating drink or cannot oppose an invitation to drink), which allows one to suggest that this poisoning happened unintentionally). It should be reminded that the Ukrainian law prohibits selling of alcohol to minors.

If "accidental" deaths are added by another 381 deaths resulting from "alcohol poisoning, with undetermined intent", it will be obvious that the scales of the losses resulting from lethal alcohol poisoning in Ukraine are significant. It should be noted that deaths of two babies younger than one year (one of them is a boy aged $0-27$ days), occurred in 2019, were classified as "alcohol poisoning, with undetermined intent".

At the same time, accidental poisonings caused by other noxious substances took far lesser number of lives (1591 cases). From the age of 30 years and on, the number of accidental poisonings and alcohol effects exceeds the number of accidental poisonings caused by noxious substances (except for alcohol) and reaches the maximum in the age of maturity (45-49 years) (Figure 3, constructed by data from the State Statistics Service of Ukraine, form C-8 "Distribution of deaths by gender, age group and cause of death"). 


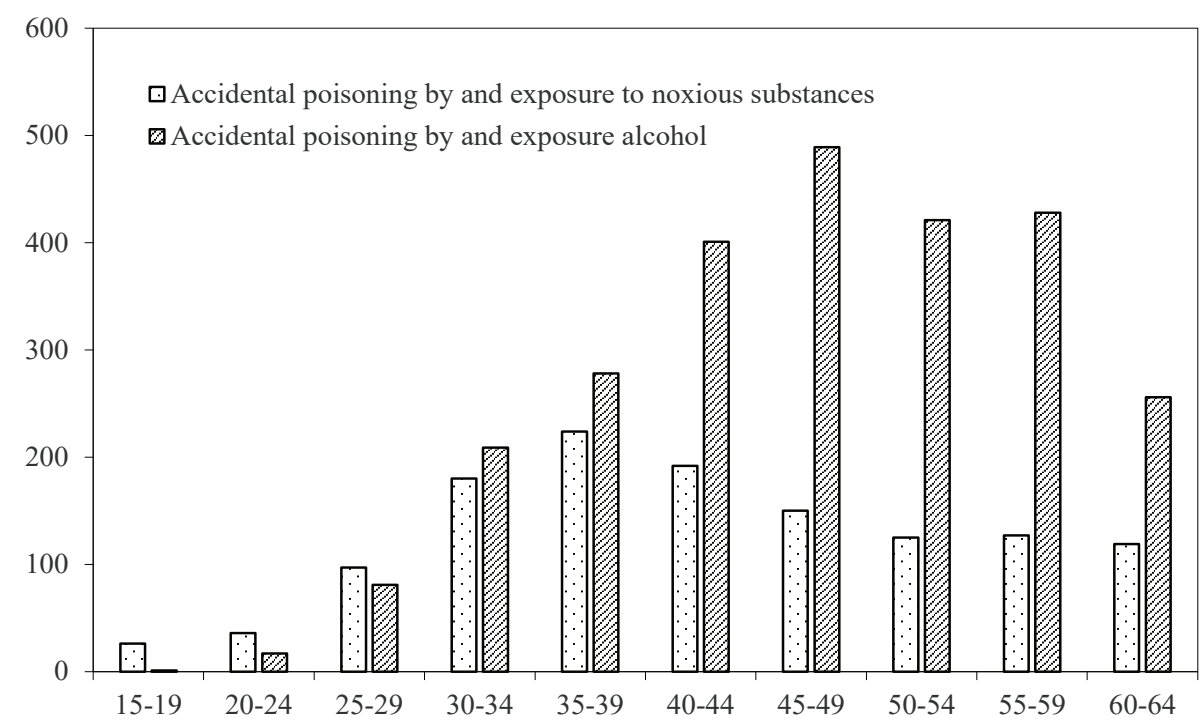

Figure 3. The distribution of deaths due to accidental poisonings caused by noxious substances, and accidental poisonings and alcohol effects, by five-year age group, Ukraine, 2019

Also, nearly twice higher number of death cases due to alcohol poisoning compared with the number of other accidental poisonings is recorded in Moscow and other big Russian cities [13].

In Ukraine, the probability to be killed is lower than the probability to drown (the classification category "accidental drowning and immersion into water' includes the accidents when a person is drowned in a water pool or puddle or so). Although the death due to drowning is associated with the highest risk of occurrence in the childhood or teenager age, statistics shows: of 1553 cases nearly half (772) occurs in the adult age from 35 to 60 years.

1252 accidents were recorded in Ukraine, caused by effects of smoke, fire and flame. The fact that nearly one person of the four is old (336 of the dead are persons of 75 years or older) should draw attention of social service officers, especially to the category of lonely old people with functional restrictions.

A comparison with the analogous distribution in EU countries (the latest available data are for 2016) shows that apart from a difference in scales, a variation in the structure is noticeable (Table 3, constructed by data from the State Statistics Service of Ukraine and Eurostat [14], the age-standardized death rate, per 100,000 of population). A similarity is that nearly one quarter of the deaths due to ECs in EU-28 are suicides (and almost one third for males). Experts relate the upsurge of mortality due to suicides in EU countries with the economic crisis. Thus, the increasing mortality of males younger than 65 years became particularly pronounced: after a reduction in 2002-2007 (from 18.2 to 15.3 per 100,000 of population in the respective age group), it grew to 16.8 in 2009 and decreased to 16.3 per 100,000 of population only by 2013 . At the same time, the crisis had no effect for a downward tendency in the mortality caused by suicides among males of 65 years and older [6]. As far as other causes are concerned, the most striking difference is observed in the share of already discussed falls (which is four times smaller in Ukraine) and harms with undetermined intent (which is nearly five times higher in Ukraine).

Table 3

The mortality due to external causes of death in EU-28 and Ukraine, both genders

\begin{tabular}{|c|c|c|c|c|}
\hline \multirow[b]{2}{*}{ Cause of death } & \multicolumn{2}{|c|}{ EU-28, 2016} & \multicolumn{2}{|c|}{ Ukraine, 2019} \\
\hline & $\begin{array}{c}\text { Figure per } 100,000 \text { of } \\
\text { population }\end{array}$ & Share, \% & $\begin{array}{c}\text { Figure per } 100,000 \text { of } \\
\text { population }\end{array}$ & Share, \% \\
\hline $\begin{array}{l}\text { External causes of morbidity and } \\
\text { mortality, including: }\end{array}$ & 47.13 & 100 & 70.5 & 100 \\
\hline $\begin{array}{l}\text { - intentional self-harms / } \\
\text { suicides }\end{array}$ & 10.75 & 22.8 & 14.2 & 20.1 \\
\hline \begin{tabular}{|l} 
- transport accidents / road \\
transport accidents
\end{tabular} & 6.02 & 12.8 & 10.3 & 14.6 \\
\hline $\begin{array}{l}\text { - accidental poisoning by and } \\
\text { exposure to noxious substances }\end{array}$ & 2.15 & 4.6 & 10.2 & 14.5 \\
\hline \begin{tabular}{|l|}
- falls \\
\end{tabular} & 11.21 & 23.8 & 4.2 & 6.0 \\
\hline $\begin{array}{l}\text { - accidental drowning and } \\
\text { submersion }\end{array}$ & 1.08 & 2.3 & 3.9 & 5.5 \\
\hline - assault & 0.69 & 1.5 & 3.3 & 4.7 \\
\hline- event of undetermined intent & 1.86 & 4.0 & 13.7 & 19.4 \\
\hline
\end{tabular}


Gender disproportions of mortality due to ECs can be found in all the countries of the world, but in Ukraine the excessive mortality of males is more significant in the majority of ECs. The share of deaths of Ukrainian males due to all ECs was $8.4 \%$, whereas for females it was only $2.0 \%$. While in EU-28 males account for nearly two thirds of the total deaths due to ECs $(64.2 \%)$, the analogous share in Ukraine is higher than $80 \%(80.2 \%)$. In the European region of WHO the mortality due to ECs is uneven as well: the mortality of males is 2.4 times higher than the one of females [4].

In spite of the reduced mortality due to ECs in time of the Ukraine's independence, the excessive mortality of males became even more noticeable and grew from 4.3 times to 5.3 times (an increase recorded for almost all the ECs), see Table 4 (constructed by data from the State Statistics Service of Ukraine, form TC-4). In 2019, the highest excessive mortality was caused by drowning (like in 1991), suicides and accidental poisonings (more than six times higher).

Table 4

Change in the mortality due to external causes of death, Ukraine, 1991 and 2019

\begin{tabular}{|c|c|c|c|c|c|c|}
\hline \multirow[b]{2}{*}{ Cause of death } & \multicolumn{3}{|c|}{1991} & \multicolumn{3}{|c|}{2019} \\
\hline & Males & Females & $\begin{array}{c}\text { Excessive } \\
\text { mortality of } \\
\text { males, times }\end{array}$ & Males & Females & $\begin{array}{c}\text { Excessive } \\
\text { mortality of } \\
\text { males, times }\end{array}$ \\
\hline $\begin{array}{l}\text { External causes of morbidity } \\
\text { and mortality, including: }\end{array}$ & 202.9 & 46.7 & 4.3 & 125.6 & 23.8 & 5.3 \\
\hline $\begin{array}{l}\text { - intentional self-harms / } \\
\text { suicides }\end{array}$ & 36.8 & 7.6 & 4.8 & 26.4 & 4.3 & 6.1 \\
\hline $\begin{array}{l}\text { - transport accidents / road } \\
\text { transport accidents }\end{array}$ & 13.7 & 9.8 & 1.4 & 17.1 & 4.2 & 4.1 \\
\hline $\begin{array}{l}\text { - accidental poisonings (except } \\
\text { for alcohol) }\end{array}$ & 13.7 & 4.3 & 3.2 & 18.4 & 3.0 & 6.1 \\
\hline $\begin{array}{l}\text { - accidental poisonings } \\
\text { (alcohol effect)* }\end{array}$ & 22.4 & 4.2 & 5.4 & $\cdots$ & $\cdots$ & $\cdots$ \\
\hline - falls & 9.1 & 2.2 & 4.1 & 7.8 & 1.4 & 5.6 \\
\hline - drowning & 16.5 & 2.6 & 6.3 & 7.3 & 0.9 & 8.1 \\
\hline - assault & 13.5 & 4.7 & 2.9 & 5.1 & 1.7 & 3.0 \\
\hline - event of undetermined intent & - & - & - & 24.3 & 4.7 & 5.2 \\
\hline $\begin{array}{l}\text { - accidents caused by smoke, } \\
\text { fire or flame }\end{array}$ & 3.1 & 1.4 & 2.2 & 4.9 & 1.1 & 4.5 \\
\hline
\end{tabular}

* Estimates are not given by the State Statistics Service of Ukraine in form TC-4 for 2019.

International comparisons. Unlike Ukraine, ECs, ranking fourth in the structure of the overall mortality, do not comprise the three main causes of death for the total population in EU. The standardized indicators of mortality due to ECs vary across countries, with more than four times difference between minimal and maximal figures.
Apart from the scopes, the mortality due to ECs in European countries differs by structure. The highest mortality is a distinct feature of new EU members, the former soviet republics (Latvia and Lithuania), which is also true for higher significance of poisonings, homicides and harms with undetermined intent (Table 5, constructed by data from Eurostat [14]).

Table 5

The mortality due to external causes of death in selected EU countries, both genders, 2016/2015

(cases per 100,000 of population)

\begin{tabular}{|c|c|c|c|c|c|c|c|}
\hline Cause of death & EU-28 & Germany & Czech & Denmark & Latvia & Lithuania* & Sweden \\
\hline $\begin{array}{l}\text { External causes, } \\
\text { including }\end{array}$ & 47.13 & 44.0 & 57.62 & 36.64 & 86.47 & 105.1 & 49.54 \\
\hline $\begin{array}{l}\text { intentional self-harm / } \\
\text { suicides }\end{array}$ & 10.75 & 11.29 & 12.57 & 10.19 & 18.56 & 28.27 & 11.73 \\
\hline transport accidents & 6.02 & 4.32 & 7.11 & 3.73 & 10.41 & 8.55 & 3.05 \\
\hline accidental poisoning & 2.15 & 1.15 & 4.36 & 3.61 & 8.21 & 14.77 & 5.54 \\
\hline accidental falls & 11.21 & 16.22 & 6.15 & 10.41 & 7.67 & 14.27 & 10.28 \\
\hline $\begin{array}{l}\text { assault and intentional } \\
\text { harms }\end{array}$ & 0.69 & 0.46 & 0.5 & 0.45 & 4.59 & 3.63 & 0.94 \\
\hline $\begin{array}{l}\text { event of undetermined } \\
\text { intent }\end{array}$ & 1.86 & 1.66 & 2.04 & 0.54 & 9.3 & 9.44 & 3.62 \\
\hline
\end{tabular}

*Data for the year of 2015 . 
Almost in all the EU countries the mortality due to ECs in the age younger than 65 has recently decreased (with slower rates in the countries with low mortality figures) by nearly $30 \%$ in average (Table 6 , constructed by data from [15]). Sweden is chosen as a reference country for comparative analysis purposes because of its stable leading position (the second one for the year of 2018) by Human Development Index and its life expectancy component. As can be seen, Ukraine had several times higher rate of sudden deaths due to ECs than Sweden, although the gap between the two countries reduced (from more than 5 times in 2002 to 2.5 times in 2016). A similar situation occurs in other former soviet republics. It should be noted that the figures of Sweden are higher than for EU-15. When a comparison is made with Italy or Spain (14.0 to 15.0 deaths per 100,000 of population) or even with Israel (13.0 deaths per 100,000 of population) as a country waging military actions, the Ukrainian realities will be even more disappointing. As regards gender aspect, in EU countries standardized figures of death due to ECs for males younger than 65 exceed the ones for the female contemporaries by more than 3.5 times, with a lesser gap in Sweden (2.8 times). As for Ukraine, the figure in question for males is 5.5 times higher!

Table 6

Rates of sudden deaths (for persons younger than 65) due to external causes in Ukraine and selected countries, both genders

\begin{tabular}{|l|r|r|r|r|}
\hline \multirow{2}{*}{ Country } & \multicolumn{2}{|c|}{$\mathbf{2 0 0 2}$} & \multicolumn{2}{c|}{$\mathbf{2 0 1 5} / \mathbf{2 0 1 6}$} \\
\cline { 2 - 6 } & $\begin{array}{c}\text { per 100,000 } \\
\text { population }\end{array}$ & $\begin{array}{c}\text { ratio to reference } \\
\text { country, times }\end{array}$ & $\begin{array}{c}\text { per 100,000 } \\
\text { population }\end{array}$ & $\begin{array}{c}\text { ratio to reference } \\
\text { country, times }\end{array}$ \\
\hline Hungary & 58 & 1,9 & 32 & 1,1 \\
\hline Lithuania* & 145 & 4,8 & 87 & 3,1 \\
\hline Latvia & 145 & 4,8 & 69 & 2,5 \\
\hline Kazakhstan & 149 & 5,0 & 85 & 3,0 \\
\hline Germany & 26 & 0,9 & 18 & 0,6 \\
\hline Moldova & 97 & 3,2 & 66 & 2,4 \\
\hline Poland & 54 & 1,8 & 36 & 1,3 \\
\hline Sweden & 30 & 1,0 & 28 & 1,0 \\
\hline Ukraine & 152 & 5,1 & 71 & 2,5 \\
\hline EU-15 & 29 & 1,0 & 20 & 0,7 \\
\hline EU-28 & 35 & 1,2 & 24 & 0,9 \\
\hline
\end{tabular}

* Data for the year of 2015.

When the mortality picture in Ukraine is compared with the one in Poland, i. e. a neighboring country with similar nature and climate conditions, close to Ukraine by ethnic composition, cultural traditions and patterns of social transformations, it can be revealed that the significance of ECs in the structure of the total mortality in Poland, in spite of the twice lower rate, is nearly the same as in Ukraine or Sweden (Table 7, constructed by data from [16;17] and the State Statistics Service of Ukraine).

Table 7

The number of deaths due to external causes and their share in the structure of mortality in Ukraine, Poland and Sweden, both genders, 2019 рік

\begin{tabular}{|l|r|r|r|r|r|r|}
\hline \multirow{2}{*}{ Cause of death } & \multicolumn{2}{|c|}{ Ukraine } & \multicolumn{2}{c|}{ Poland } & \multicolumn{2}{c|}{ Sweden } \\
\cline { 2 - 7 } & $\begin{array}{l}\text { Absolute figure, } \\
\text { thousand cases }\end{array}$ & Share, \% & $\begin{array}{l}\text { Absolute figure, } \\
\text { thousand cases }\end{array}$ & Share, \% & $\begin{array}{l}\text { Absolute figure, } \\
\text { thousand cases }\end{array}$ & Share, \% \\
\hline $\begin{array}{l}\text { All the causes, } \\
\text { including: }\end{array}$ & 581.1 & 100 & 107.8 & 100 & 88.8 & 100 \\
\hline $\begin{array}{l}\text { CLASS XX. } \\
\text { External causes of the } \\
\text { mortality }\end{array}$ & 30.0 & 5.2 & 5.2 & 4.8 & 4.9 & 5.5 \\
\hline
\end{tabular}

Megalopolises and mortality due to ECs. A comparison of the situation with mortality due to ECs in large cities of European countries shows clear differences in scopes and significance of main causes. Of the analyzed megalopolises, the lowest rates are found in the capital of the United Kingdom. Also, the share of ECs in the structure of the overall mortality differs and fluctuates from the highest one in Hamburg to the lowest one in Bucharest (Table 8, constructed by data from [14] and the State Statistics Service of Ukraine). In Wien, Prague and Berlin, where the mortality rates are similar, the shares of ECs are quite the same $(4-4,3 \%)$, whereas in the large port city of Hamburg the significance of ECs was the highest 
(6.4\%) given nearly the same mortality rate. In Kyiv, almost $5 \%(4.9 \%)$ of all deaths are caused by ECs.

Russian researchers stress that Moscow lags behind a number of foreign megalopolises by mortality rate mainly because of high figures of the mortality due to ECs (along with deceases of blood circulation

system) [14]. This is despite the fact that the mortality rate in Moscow (like in Kyiv) is far lower than in the majority of regions in each country. This is despite the fact that the mortality rate in Moscow (like in Kyiv) is far lower than in the majority of regions in each country, i. e. Russia and Ukraine).

Table 8

Mortality rates due to external causes of death in selected megalopolises of EU and the city of Kyiv, both genders

\begin{tabular}{|c|c|c|c|}
\hline \multirow[b]{2}{*}{ City } & \multirow{2}{*}{$\begin{array}{l}\text { All the causes, } \\
\text { per } 100,000 \text { population }\end{array}$} & \multicolumn{2}{|c|}{ External causes } \\
\hline & & per 100,000 population & $\begin{array}{c}\text { share of the total } \\
\text { causes, \% }\end{array}$ \\
\hline London & 859.7 & 26.4 & 3.1 \\
\hline Bucharest & 1388.6 & 34.4 & 2.5 \\
\hline Berlin & 996.1 & 40.1 & 4.0 \\
\hline Wien & 959.8 & 41.1 & 4.3 \\
\hline Prague & 1082 & 45.7 & 4.2 \\
\hline Hamburg & 982.4 & 62.6 & 6.4 \\
\hline Kyiv & 930.7 & 45.6 & 4.9 \\
\hline
\end{tabular}

Table 9 (constructed by data from [14] the State Statistics Service of Ukraine) illustrates the varying significance of certain external causes of death in European megalopolises. Kyiv stands out by the high rate and share of deaths recorded as harm with

undetermined intent. For cities like London, Wien, Prague or Berlin, one of the most significant causes of unnatural death is suicide, whereas in Bucharest one of the four deaths due to ECs resulted from road traffic accidents.

Table 9

The mortality by external cause of death in selected megalopolises of EU and in the city of Kyiv, both genders

\begin{tabular}{|l|r|r|r|r|r|r|r|}
\hline \multirow{2}{*}{ City $^{*}$} & \multirow{2}{*}{$\begin{array}{c}\text { All the } \\
\text { ECs }\end{array}$} & \multicolumn{2}{|c|}{ Suicide } & \multicolumn{2}{c|}{ Road traffic accident } & \multicolumn{2}{c|}{$\begin{array}{c}\text { Event with undetermined } \\
\text { intent }\end{array}$} \\
\cline { 3 - 8 } & & $\begin{array}{c}\text { per 100,000 } \\
\text { population }\end{array}$ & share, \% & $\begin{array}{c}\text { per 100,000 } \\
\text { population }\end{array}$ & share, \% & $\begin{array}{l}\text { per 100,000 } \\
\text { population }\end{array}$ & \multicolumn{1}{c|}{ share, \% } \\
\hline London & 26.4 & 4.82 & 18.3 & 1.2 & 4.5 & 1.66 & 6.3 \\
\hline Bucharest & 34.4 & 3.7 & 10.8 & 8.8 & 25.6 & 0.83 & 2.4 \\
\hline Berlin & 40.1 & 10.5 & 26.2 & 2.15 & 5.4 & 3.0 & 7.5 \\
\hline Wien & 41.1 & 11 & 26.8 & 2.9 & 7.1 & 6.06 & 14.7 \\
\hline Prague & 45.7 & 10.9 & 23.9 & 5.1 & 11.2 & 1.43 & 3.1 \\
\hline Hamburg & 62.6 & 13.3 & 21.2 & 3.1 & 5.0 & 0.91 & 1.5 \\
\hline Kyiv & 45.6 & 4.9 & 8.0 & 5.8 & 12.7 & 22.6 & 49.6 \\
\hline
\end{tabular}

* Data are for 2016 for EU cities, and 2019 for Kyiv.

\section{Conclusions}

1. The high mortality rate due to ECs in Ukraine, which is nearly twice higher than in EU countries and features a considerable excessive mortality of males, is responsible for a large share of losses of human lives (including in young and middle age).

2. Ukraine features a concentration of deaths due to ECs in the age younger than 65 . This age group accounted for nearly $80 \%$ of deaths due to ECs (against 49\% in EU countries) in 2019, but lesser than $30 \%$ of the total deaths (against 13\% in EU countries

3. The rate of sudden mortality (in the age anger than 65) due to ECs in Ukraine is several times higher than in Sweden (chosen as a reference country), although the gap between the countries reduced (from more than five times in 2002 to 2.5 times in 2016).
4. Ukraine features essential gender disproportions of the mortality due to ECs both in mortality rate and structure. The share of deaths of Ukrainian males due to ECs made $8.4 \%$, against only $2.0 \%$ for females. In 2019, the highest excessive mortality was due to causes like drowning, suicides or accidental poisonings (with the excess from six to more than eight times).

5. The excess of males dead due to ECs in Ukraine is much more significant than in developed countries of Europe: in EU-28, males account for less than two thirds $(64.2 \%)$ of the total deaths due to ECs, against nearly $80 \%$ (as exactly as $80.2 \%$ ) in Ukraine.

6. A pressing social problem for modern Ukraine is the excessive mortality due to accidental poisoning and alcohol effects: from the age of 30 years 
and on, the number of such cases exceeds the number of poisonings caused by noxious substances, reaching the maximum in the age of maturity ( $45-49$ years).

7. More than seven times higher rate of mortality classified as "event of undetermined intent" than in EU-28 and its second rank of significance in the structure of the total deaths due to ECs in Ukraine poses a question about the need for a review of the accuracy of determining death causes and for quality improvement of the official statistics of mortality in this class of causes.
Areas of further research. The need to elaborate effective measures on reducing losses resulting from the mortality due to ECs raises the relevance of research specifically devoted to "event of undetermined intent". Cleaning up this "dower chest" containing the unjustifiably high share of the total deaths due to ECs in Ukraine is a required step in improving the quality of statistics and understanding the real picture and tendencies of change in the epidemiological situation with respect to the external causes of mortality.

\section{References}

1. Vishnevskiy, A. G. (Ed.). (2017). Smertnost ot vneshnikh prichin v Rossii s serediny XX veka [Mortality from External Causes in Russia since the mid-20th Century]. Moscow: Izdatelskiy dom NIU VSHE [in Russian].

2. Vishnevskiy, A. G. (2014). Smertnost v Rossii: nesostoiavshaiasia vtoraia epidemiologicheskaia revolyutsiia [Mortality in Russia: the failed second epidemiological revolution]. Demograficheskoe obozrenie - Demographic Review, 4, 5-40. Retrieved from https:/demreview.hse.ru/data/2015/05/25/1096965856/ DemRev_1_4_2014_5-40.pdf [in Russian].

3. WHO. (2014). Global status report on violence prevention 2014. Retrieved from https://www.who.int/ violence_injury_prevention/violence/status_report/2014/en/

4. WHO Regional Office for Europe. (2020). Violence and injuries in Europe: burden, prevention and priorities for action. apps.who.int. Retrieved from https://apps.who.int/iris/bitstream/hand le/10665/332919/9789289055109-eng.pdf

5. Injury Mortality in the United States, 1999-2016. wrow.cdc.gov. Retrieved from https://www.cdc.gov/ nchs/data-visualization/injury-mortality/

6. Scherbakova, E. M. (2016). Smertnost ot vneshnih prichin v ES-28 [Mortality from external causes in the EU-28]. Demoskop Weekly, № 705-706. Retrieved from http://demoscope.ru/weekly/2016/0705/ barometer705.pdf [in Russian].

7. Yumaguzin, V. V. (2013). Smertnost ot vneshnih prichin v Rossii v postsovetskiy period [Mortality from external causes in Russia in the post-Soviet period]. Candidate's thesis. Moscow [in Russian].

8. Yumaguzin, V. V., Vinnik, M.V. (2019). Otsenka realnogo urovnia ubiysto $i$ samoubiystv v regionah Rossii [Assessment of the Real Rates of Homicides and Suicides in the Regions of Russia]. DOI: 10.31857/ S013216250003753-1 [in Russian].

9. Andreev, E. M., Shkolnikov, V. M., Pridemore, W. A., Nikitina, S. Yu. (2015). A Method for Reclassifying Cause of Death in Cases Categorized as "Event of Undetermined Intent". Population Health Metrics, Vol. 13, Art. 23.

10. Danilova, I. A. (2014). Smertnost pozhilyih ot vneshnih prichin v Rossii [Mortality of the elderly from external causes in Russia]. Demograficheskoe obozrenie - Demographic Review, 2, 57-84 [in Russian].

11. Vasin, S. (2015). Smertnost ot povrezhdeniy s neopredelennymi namereniiami v Rossii i v drugih stranah [Mortality from undetermined causes of death in Russia and in a selected set of countries]. Demograficheskoe obozrenie - Demographic Revier, 2 (1), 89-124. Doi: 10.17323/demreview.v2i1.1790 [in Russian].

12. Tomkins, S., Collier, T., Oralov, A., Saburova, L., McKee, M., Shkolnikov, V. \& et al. (2012). Hazardous Alcohol Consumption is a Major Factor in Male Premature Mortality in a Typical Russian City: Pro-spective Cohort Study 2003-2009. PLoS ONE, Vol. 7 (2). Doi: 10.1371/journal.pone.0030274

13. Andreev, E., Kvasha, E., \& Kharkova, T. (2016). Mortality in Moscow and other megacities of the world: similarities and differences. cyberleninka.ru. Retrieved from https://cyberleninka.ru/article/n/mortality-inmoscow-and-other-megacities-of-the-world-similarities-and-differences 


\section{Н. О. Рингач,}

доктор наук з державного управління, старший науковий співробітник, головний науковий співробітник,

Інститут демографії та соціальних досліджень

імені М. В. Птухи НАН України,

E-mail: n_ryngach@ukr.net; n_ryngach@idss.org.ua

ResearcherID: X-3983-2018,

ORCID: https://orcid.org/0000-0002-5916-3221

\section{Смертність унаслідок зовнішніх причин в Україні: життя, які можна було зберегти}

Мета роботи - оцінити втрати людського життя в результаті смертності внаслідок зовнішніх причин в Україні (абсолютну кількість, рівень і структуру) та визначити особливості залежно від статі та віку з розподілом за основними причинами. На основі даних Державної служби статистики України щодо розподілу померлих за статтю, віком і причинами смерті, а також міжнародних і національних баз даних здійснено компаративний аналіз смертності в результаті зовнішніх причин з іншими країнами. Показано, що основну частку смертей зумовили чотири основні причини, на які припадало понад $68 \%$ усіх випадків: навмисні самоушкодження (самогубства); ушкодження з невизначеним наміром; випадкові отруєння, спричинені отруйними речовинами; транспортні нещасні випадки.

Виявлено суттєву диспропорцію смертності внаслідок зовнішніх причин залежно від статі: рівень смертності чоловіків у 4,7 раза вищий, ніж жінок. В Україні на чоловіків припадає 80,2\% усіх загиблих унаслідок зовнішніх причин (у СС-28 - дві третини, 64,2\%). Переважання чоловіків найбільш вагоме за такими причинами, як утоплення, самогубства і випадкові отруєння (з перевищенням відповідного показника для жінок від шести до понад восьми разів). Відповідно у загальній структурі смертності частка смертей унаслідок зовнішніх причин для українських чоловіків була вищою $(8,4 \%)$, ніж для жінок $(2,0 \%)$.

Рівні передчасної смертності (у віці 0-64 роки) унаслідок зовнішніх причин смерті в Україні у два з половиною рази перевищують показники Швеції, вибраної за країну-еталон, та втричі - рівень ЄС-15. При цьому в Україні у віці 0-64 роки сконцентрована більшість смертей: у 2019 році майже $80 \%$ смертей припадало на вік молодше за 65 років (у країнах $Є C-28$ - 49\%).

Гострою соціальною проблемою сучасної України є надмірна смертність унаслідок випадкових отруєнь та дії алкоголю: починаючи з 30-річного віку, кількість таких випадків перевищує кількість отруєнь, спричинених отруйними речовинами. Їх число для всього населення вище в 1,75 раза, а у зрілому віці (45-49 років) - понад утричі (у 3,25 раза).

Сфокусовано увагу на проблемі зростання числа випадків смерті, класифікованих як "ушкодження з невизначеним наміром" (у понад сім разів вищий рівень порівняно з СС-28). Це актуалізує необхідність аналізу достовірності визначення причин смерті та підвищення якості офіційної статистики смертності за цим класом причин в Україні для кращого розуміння реального стану і тенденцій змін епідеміологічної ситуації щодо зовнішніх причин смертності.

Ключові слова: смертність, зовнішні причини смерті, навмисні ушкодження, неумисні ушкодження, структура за основними причинами смерті, самогубства, випадкові отруєння, спричинені отруйними речовинами, транспортні нещасні випадки, вбивства, ушкодження з невизначеним наміром, демографічні втрати, передчасна смертність.

Bibliographic description for quoting:

Ryngach, N. O. (2020). Mortality Due to External Causes in Ukraine: Lives That Could Be Saved. Statystyka Ukrainy - Statistics of Ukraine. 2-3.96-106. Doi: 10.31767/su.2-3(89-90)2020.02-03.11.

Бібліографічний опис для цитування:

Рингач Н. О. Смертність унаслідок зовнішніх причин в Україні: життя. які можна було зберегти (публікується англійською мовою). Статистика України. 2020. № 2-3. С. 96-106. Doi: 10.31767/su.2-3(89-90)2020.02-03.11. 